\title{
Resenha elaborada por Maria Catarina Chitolina ZANINI ${ }^{1}$ (UFSM)
}

GASPAR, Rafael Bezerra. O Eldorado dos gaúchos. Deslocamentos de agricultores do sul do país e seu estabelecimento no leste maranhense. São Luis: EDUFMA/FAPEMA, 2013.

\section{TEXT REVIEW:}

Rafael Bezerra Gaspar.

A obra de Rafael Bezerra Gaspar, denominada O Eldorado dos Gaúchos, fruto de sua dissertação de mestrado defendida na UFMA (Universidade Federal do Maranhão), no Programa de Pós-Graduação em Ciências Sociais, sob orientação de Maristela de Paula Andrade, apresenta o panorama histórico e humano da chegada dos denominados "gaúchos" no Leste do Maranhão. Trata-se de um processo migratório que se configura com especificidades particulares vinculadas ao crescimento do "agronegócio" na região e que tem seu início nos anos 80 do século passado.

Embora denominados genericamente como gaúchos, o autor ressalta que esses agricultores são provenientes de várias localidades e que o descritivo gaúcho se refere mais ao distintivo "de fora", especialmente daqueles originários do Sul do país. A obra está organizada em capítulos monográficos nos quais são apresentados o tempo e o espaço da pesquisa empírica, bem como a metodologia estudada e os dados obtidos em campo. Trata-se de um estudo bem feito, cuidadoso nas observações e atento ao campo. Com uma inclinação por autores, como Pierre Bourdieu e Norbert Elias, o autor procura apontar quais seriam os agentes que, no campo específico do "agronegócio" maranhense, disputavam terra, distinção e outros elementos.

No Capítulo 1, denominado Questões e caminhos, o autor traça um panorama da região, seu povoamento e especificidades. Com forte influência recebida de sua orientadora (Maristela Paula Andrade), o que se observa é a construção de um problema de pesquisa conciso: "Como os agricultores gaúchos se classificam em relação a outros grupos? Quais os critérios utilizados em uma diferenciação interna entre eles? $\left(2013\right.$, p.37) ${ }^{2}$, bem como compreender como se configuraram os processos migratórios dos gaúchos para o Leste maranhense e quais as estratégias por eles utilizadas no processo de fixação na região. Nesse capítulo o autor aponta

\footnotetext{
${ }^{1}$ Professora Titular do Departamento de Ciências Sociais da UFSM (Universidade Federal de Santa Maria). Doutora em Antropologia Social pela USP (Universidade de São Paulo).

${ }^{2}$ Igualmente, como ressalta o autor: "interessa mapear as condições com as quais esses agricultores se deslocaram de seu local de origem ou de outras áreas em que estavam fixados, assim como as estratégias empreendidas para se estabelecerem na mesorregião Leste Maranhense." (2013, p.37).
} 
para o papel do Estado na colonização da região por meio da atração do denominado "agricultor moderno", num processo de abertura de fronteiras e de colonização programada.

Como o autor ressalta no capítulo, apesar de receoso acerca da recepção da pesquisa por parte dos gaúchos, considerados o grupo dominante local, esta se desenvolveu bem, contrariando, como ele aponta, o que Pinçon e Pinçon-Charlot (2007, p.24) assinalaram, ou seja, de que as classes abastadas geralmente "sabem se manter no seu lugar e colocar o sociólogo no seu" (2013, p.53). Apesar do temor, segundo Gaspar, a receptividade da pesquisa foi boa. O pesquisador fez uso de conversas informais não gravadas, bem como de entrevistas gravadas baseadas em roteiro semi-estruturado, optando pela utilização de nomes fictícios. $\mathrm{O}$ foco da pesquisa recaiu sobre os denominados gaúchos antigos, ou seja, aqueles que haviam chegado primeiro à região e que seriam considerados os porta-vozes do grupo. O pesquisador contou também com a colaboração de uma informante potencial denominada Rosário Sousa, funcionária pública aposentada na casa da qual se hospedou. Foi essa colaboradora que o inseriu mais facilmente no campo, usando, espacialmente o recurso do telefone e de suas relações com os gaúchos mais antigos. A pesquisa concentrou-se nas localidades de Chapadinha e Anapurus. Como ressalta o autor:

O próprio tema da pesquisa tornou-se um elemento de empatia dos pesquisados para com o pesquisador, fato que os deixou seguros para elaborarem quadros memorialísticos de extrema relevância para o andamento da pesquisa. (2013, p.62).

No capítulo II o autor se detém mais especificamente no processo histórico de ocupação do cerrado antes da chegada dos gaúchos. Aliás, a construção histórica presente na obra é um de seus pontos fortes. Nesse espaço, o autor também apresenta a geografia da região, entre suas chapadas e baixões, sua vegetação e especificidades naturais. Como aponta Gaspar, os gaúchos, desde sua chegada nos anos 80 , sempre circularam, ocupando terras extensivamente.

O capítulo III, denominado Os gaúchos, é uma discussão muito bem articulada acerca da complexidade dessa categoria. Utilizando a explicação elaborada pelos próprios agentes, Gaspar aponta como essa categoria é atribuída de fora, bem como incorporada, servindo como autodefinição. Por meio da utilização da concepção de grupo étnico de Frederik Barth, Gaspar aponta para a força dessa categoria nos contextos interativos. Interessante observar, por meio das narrativas apresentadas pelo autor, quais atributos podem ser acrescidos à categoria gaúcho e quais não, como ressaltou um entrevistado dizendo que não existiria uma "gaúcha preta" (2013, p.87).

Um dos elementos atribuídos e autodefinidores na construção da categoria gaúcho é o trabalho, que nos remonta para a elaboração identitária dos camponeses migrantes do Sul do 
Brasil, para os quais a categoria trabalho é um atributo moral extremamente importante. Esses gaúchos são, igualmente, migrantes e Gaspar assinala em alguns momentos da obra para esta característica importante. Descendentes, alguns deles, de imigrantes alemães e italianos que colonizaram o Sul do Brasil, o processo de migração interna se apresenta para eles como uma possibilidade de reprodução da condição de produtores rurais.

Elaborando estatísticas próprias, Gaspar nos apresenta os ciclos produtivos e um pouco do contexto econômico, político e social em que a categoria gaúcho e seus atributos passam a fazer sentido. O seja, como produto central, a soja e seu plantio, torna-se uma marca desses produtores. O tamanho de suas propriedades também. Além disto, embora o autor não aponte para isto, a idéia de poupança para capitalizar a família é algo muito importante para os descendentes de imigrantes alemães e italianos do Sul do Brasil, o que possibilita que estejam constantemente comprando mais terra objetivando possibilitar aos filhos o acesso à terra.

No Capítulo IV, denominado de Deslocamentos e estratégias dos gaúchos, o autor aponta a agência destes produtores rurais que estabelecem estratégias para se manter e ascender como produtores rurais na região. Nesse capítulo, o autor analisa a construção do gaúcho por meio de sua ascendência sulista e de colonizadores europeus, apontando que a terra se torna um elemento para 'crescer e progredir'. Aliás, a ideia de propriedade é algo muito caro a esses gaúchos. Na busca por manter a condição de produtor rural, a migração interna se torna uma estratégia possível e viável, como ressalta Gaspar:

Assim, migrar é resultado da busca constante de acesso à terra e da fixação em um lugar que propicie a oportunidade de estabelecimento como produtores agrícolas independentes que signifique a possibilidade de crescimento econômico e social do núcleo familiar. (2013, p.137).

Nesse processo, terra, família e soja se mesclam possibilitando, quando a terra fica escassa, a ampliação de novas fronteiras em que se possa reproduzir a condição de produtor rural num determinado nível de lucratividade, fazendo com que os espaços sejam adentrados com estes cultivos.

Em suma, trata-se de um estudo muito bem conduzido, criativo e que nos apresenta uma situação particular do Nordeste brasileiro: a entrada da soja e dos gaúchos como elementos dominantes na paisagem humana e econômica. Pergunta-se, para estudos futuros: e as populações nativas como têm reagido a isto? O estudo de Gaspar merece ser lido, com certeza, pois nos remete a este dilema e a estes encontros entre diferentes formas de se trabalhar e viver da terra. 